\section{Science in the Durham Colleges}

THe Durham Colleges division of the University of Durham is launching an appeal for $£ 250,000$ towards its development programme, the primary object of which is to raise the numbers of its undergraduate and postgraduate students in science from 400 to 1,000 , within the framework of an expansion of the total student body to 2,000. The erection of a new building to house the departments of chemistry and geology is to commence in 1958 ; this will permit additional space to be allocated to physics, botany and zoology. In 1959 it is proposed to begin work on a school of applied physics, the first subject within the Faculty of Applied Science to be taught in the division. It is hoped that the building will form the first unit of a much larger physics department. To accommodate the students, 700 extra residential places are required, and during 1957 a new men's college, the eleventh of Durham's colleges and societies, is to be founded.

Particular emphasis is placed upon the research needs of the pure science departments, and funds are to be allocated for the further development of nuclear research, both physical and radiochemical, and for the completion of laboratories for geophysies and geochemistry. A generous donation of $£ 50,000$ has already been received from the Sir James Knott Trusteos towards research in physics. In the quiet atmosphere of a small university and cathedral city, Durham has ample space in which to expand its facilities for both teaching and residence. But it cannot achieve its full objects without private support as well as government backing.

\section{British Museum (Natural History)}

A DEVICE to show some aspects of natural history by means of coloured stereoscopic photographs has recently been completed in the central hall of the British Museum (Natural History). Stereo-pairs of photographs are projected on a 3 -ft. screen to be viewed through five polarizing windows. A sequence of twelve scenes is shown automatically, but for special demonstrations a lecturer can exercise independent manual control and a larger audience using polarizing spectacles can be accommodated. Coloured stereo-photographs of some of the sea birds now nesting on Anglesey and on the uninhabited island of Priestholm (north-east of Anglesey) have been taken by the Museum photographic staff, and the first set is now on view. The photographs will be changed at fairly frequent intervals, and other aspects of natural history will be illustrated later. It is hoped that the apparatus will supplement the specimens on view in the galleries by providing vivid impressions of habitats, breeding cycles and other activities of many different groups of animals.

Among the more important recent acquisitions of the British Museum (Natural History) is the collection of the late Mr. A. G. Davis, who died in March, consisting of more than 200,000 fossil specimens, mainly invertebrates from the Lower Tertiary and Quaternary deposits of southern England, all collected with precision and very fully documented. Among them are numerous choice specimens, and many are from localities (including temporary sections) hitherto unrepresented in the Museum collections.

\section{Plastics Industry Education Fund}

A FURTher series of grants has recently been made to a number of technical colleges by the Plastics
Industry Education Fund. A second scholarship--in addition to that founded last year-worth $£ 300$ per annum, tenable for three years for a full-time course leading to the associateship of the Plastics Institute, has been established at the National College of Rubber Technology, London. $£ 1,000$ has been allotted to the Borough Polytechnic, London, for the academic year 1957-58, to continue the payment of a number of existing bursaries to students entering the second year of the course for the diploma of the Plastics Institute; and a further $£ 1,000$ is provided to enable four scholarships to be awarded to students taking the four-year sandwich course in applied chemistry and chemical technology (group $A$, plastics), which is to start in September at the Borough Polytechnic, leading to the new diploma in technology. The Fund has agreed to set aside $\mathfrak{£ 6 5 0}$ per annum for five scholarships for students taking the four-year sandwich course, which will start next year at the Birmingham College of Technology, together with $£ 1,000$ for three scholarships for the one-year postgraduate diploma course in high polymer technology. Two awards, each of $£ 100$ annually, are to be made to Acton Technical College for four years for students taking the sandwich course in applied chemistry with plastics chemistry as their special subject.

\section{National Museums, Ceylon}

THE Administration Report of the Director of the National Museums, Ceylon, for 1955 (pp. 32 ; Colombo: Government Publications Bureau, 1957) states that steps have been taken to initiate the building of the long-delayed northern extension. Judging by the large number of museums which have taken or are taking similar steps, it is certain that the 1950's will be remembered as a period of museum building on a wide scale. More than 180,000 visitors for the year are recorded, of which more than 25,000 were school children. Active archæological excavations were undertaken at Colombo, and a cave with a subterranean lake was investigated. Other departments undertook field expeditions, the results of which were examined by a scientific staff under the directorship of Mr. P. E. P. Deraniyagala. The report also includes a record of the work carried out a the Kandy, Ratapura and Jaffna Nationa] Museums.

\section{Lunda and Zambezi Masks}

We have become accustomed to a very high standard of scholarship and production in the publications of the Dundo Museum under its late curator, M. J. Janmart. It is delightful to find that both these standards are being maintained in a new volume by $M$. Redinha, who is now in charge of the Museum. The present excellent work (Companhia de Diamantes de Angola, Servicos Culturais. Publicacoes Culturais No. 31: Máscaras de Madeira da Lunda e Alto Zambeze. Por José Redinha. Pp. $70+$ 28 plates. Lisboa: Companhia de Diamantes de Angola, 1956) consists largely of twenty-eight fullpage illustrations in colour of various masks found in the Lunda and upper Zambezi areas, together with a brief description of each. These masks are mostly made of wood, and are at present exhibited in the Museum. In a short introduction-written in Portuguese, French and English-an account of these masks and their use is given. A favourite mask is the feminine Mwana-pwo, and when it is worn by a man while dancing he has to imitate female expres- 